$\begin{gathered}\text { Науковий вісник НЛтУ України } \\ \text { Scientific Bulletin of UNFU } \\ \text { http://nv.nltu.edu.ua }\end{gathered}$
$\begin{gathered}\text { https://doi.org/10.15421/40280530 } \\ \text { Article received 12.05.2018 p. } \\ \text { Article accepted 31.05.2018 p. } \\ \text { Удк 004.891:684.4.05 1994-7836 (print) }\end{gathered}$

Ю. І. Грицюк, К. Я. Воврин

Національний університет "Львівська політехніка", м. Львів, Україна

\title{
ПРОГРАМНЕ ЗАБЕЗПЕЧЕННЯ ДЛЯ ПОБУДОВИ СКЛАДНИХ ГЕОМЕТРИЧНИХ ПОВЕРХОНЬ ЗА ДОПОМОГОЮ СПЛАЙН-ФУНКЦІЙ
}

Розроблено програмне забезпечення для побудови складних геометричних поверхонь природного походження - стовбура деревини за допомогою сплайн-функцій, що дає змогу підвищити точність та достовірність ії̈ обліку за різними розмірними характеристиками, а також випиляних з них пиломатеріалів у галузі деревообробки. З'ясовано, що метод побудови математичних моделей твірних поверхонь поперечного перерізу колод і їх поверхонь вздовж осі дає змогу на основі єдиного теоретичного підходу описати їх розміри та форму осей і зовнішніх поверхонь. Він заснований на вимірюванні координат певної кількості точок поперечного перерізу стовбура деревини уздовж її довжини і подальшої інтерполяції точкового базису. Встановлено, що математичний апарат - інтерполяційні кубічні сплайни, побудовані на невеликій кількості точок поверхні, дають змогу з достатньою точністю визначити розмірні показники і врахувати особливості форми стовбурів деревини (кривизну, збіжність, овальність), а також є адекватними індивідуальними моделями для обліку колод як деревини, так і випиляних $з$ них пиломатеріалів. Реалізовано програмне забезпечення для побудови твірних поверхонь стовбурів деревини складної геометричної форми, яке дає змогу здійснити побудову моделей поверхонь колод сплайн-функціями. Наведено алгоритми обліку стовбура деревини і окремі алгоритми схем розкрою колод на пиломатеріали. Досліджено, що вихід пиломатеріалів після здійсненого математичного моделювання значно збільшується порівняно 3 класичними способами моделювання поверхонь колод. Встановлено, що метод індивідуальних моделей стовбурів деревини, їх математична, програмна й апаратна підтримка у вигляді математичних моделей, алгоритми реалізації та програмне забезпечення, результати і висновки поданих досліджень можуть бути використані при проектуванні виробничо-технологічних систем деревообробки, створення відповідних ресурсоощадних технологічних процесів на основі сучасного технологічного та вимірювального обладнання, методів і моделей інформаційних технологій.

Ключові слова: інформаційні технології; програмний проект; стовбур деревини; поперечний переріз колоди; твірна поверхня; річні кільця; схема розкрою; пиломатеріали; технологічне обладнання; ресурсоощадний технологічний процес.

Вступ. В даний час немаловажне значення мають раціональне використання сировинних і енергетичних ресурсів, оперативне оптимальне планування й управління виробничою діяльністю на підприємствах (Hrytsiuk, $\&$ Koshyrets, 2014). Важливим тут $є$ перехід на маловідходну, ресурсозберігаючу технологію розкрою колод на пиломатеріали і заготовки, що забезпечує максимально повне і комплексне використання стовбура деревини (Gryciuk, \& Koshyrets, 2009). Вирішення цієї проблеми $\epsilon$ життєво необхідним, позаяк йдеться про значні обсяги відходів цінної деревини (до 10 млн. м³), тому наукові дослідження в цій області знань - надзвичайно актуальні (Gryciuk, \& Yatsyshyn, 2007).

Однак, на даний момент не розвинені загальні методи побудови моделей об'єкта розкрою з урахуванням комплексу технологічних особливостей устаткування й подальших виробничих процесів при постановці завдання оптимізації розкрою деревних матеріалів, відсутній вихід на типові розрахунки з використанням оптимізаційних моделей, не вивчені методологічні принципи розроблення таких моделей $з$ адаптацією до пос- тійної зміни виробничих і технологічних умов (Yakovlev, 1995), слабо досліджені індивідуальні особливості процесу розкрою дефектних колод на пиломатеріали.

Для вирішенні цих питань найбільш оптимальним i результативним виявився метод моделювання складних геометричних поверхонь природного походження за допомогою сплайн-функцій (Zavialov, Kvasov \& Miroshnichenko, 1980; Makarov \& Khlobystov, 1993; Stechkin \& Subbotin, 1976). Знаючи координати точок, наприклад, на поверхні стовбура деревини можна змоделювати ії поперечний переріз у вигляді еліпса чи іншої складної геометричної фігури. Проте, такі характеристики поверхні стовбура деревини як його кривизна, збіжність та дефекти не завжди можна врахувати, немаючи для цього достовірної методики їх врахування, що призведе до не зовсім адекватної математичної моделі i, як наслідок, до подальших втрат деревини у відходи та якості випиляних пиломатеріалів (Hrytsiuk \& Koshyrets, 2014; Filiptcov, 2010; Yakovlev, 1995).

Аналіз останніх досліджень та публікацій. При пошуку адекватної моделі твірної поверхні стовбура де-

\section{Інформація про авторів:}

Грицюк Юрій Іванович, д-р техн. наук, професор кафедри програмного забезпечення. Email: yurii.i.hrytsiuk@lpnu.ua; ORCID: http://orcid.org/0000-0001-8183-3466; ResearcherlD: V-3995-2017

Воврин Катерина Ярославівна, студентка, кафедра програмного забезпечення. Email: kateryna.vovryn@gmail.com Цитування за ДСтУ: Грицюк Ю. І., Воврин К. Я. Програмне забезпечення для побудови складних геометричних поверхонь за допомогою сплайн-функцій. Науковий вісник НЛТУ України. 2018, т. 28, № 5. С. 147-156.

Citation APA: Hrytsiuk, Yu. I., \& Vovryn, K. Ya. (2018). Software for construction of complex geometric surfaces with spline functions. Scientific Bulletin of UNFU, 28(5), 147-156. https://doi.org/10.15421/40280530 
ревини було знайдено рішення, яке полягає у використанні кубічних інтерполяційних сплайнів, що, як потім виявилося, $є$ найбільш точною моделлю 3 мінімальною кількістю затребуваних даних (Yakovlev, 1995).

Сплайнами називають функції, що складені із многочленів певних степенів згідно 3 деякою системою (Makarov \& Khlobystov, 1993). Найпростішим сплайном є ламана лінія, тобто складається 3 лінійних многочленів (Stechkin \& Subbotin, 1976). Форму сплайна має пружна балка із точковими навантаженнями, вивченням форм яких займався ще Ленардо да Вінчі. Розвитку теорії сплайн-наближень сприяли роботи таких математиків: І. Шенберг, Е. Нільсон, В. М. Тихомиров, С. Б. Стечкін, В. Л. Макаров, Ю. С. Зав'ялов й інші.

Аналіз застосування сплайнів як математичного апарату наближення функцій в числовому аналізі показує, що в усіх відомих випадках вдавалося домогтися відчутних результатів порівняно 3 класичним апаратом многочленів (Zavialov, Kvasov \& Miroshnichenko, 1980; Stechkin \& Subbotin, 1976). У одних задачах перехід до кубічних сплайнів приводить до підвищення точності отриманих результатів, у других - до значного скорочення обчислювальних витрат (Yatsyshyn \& Gryciuk, 2007).

Не претендуючи на кардинальні зрушення в теорії сплайн-функцій, спробуємо внести і свою лепту в практичне їх застосування, особливо у галузь деревообробки для опису твірних поверхонь стовбурів деревини як у поперечному перерізі, так і вздовж осі. Тому, як на сьогодні, видається нам актуальним проведення дослідження, яке стосується розроблення адекватної методики візуального подання твірної поверхні поперечного перерізу колоди, іiї річних кілець, а також поверхні колоди вздовж іiі осі, що дасть змогу підвищити точність та достовірність обліку стовбурів деревини як промислової сировини в галузі деревообробки.

Об'єкт дослідження - складні геометричні поверхні природного походження.

Предмет дослідження - методи та засоби побудови складних геометричних поверхонь природного походження сплайн-функціями як у дво-, так і тривимірному вигляді, що дасть змогу підвищити точність та достовірність визначення площ і об'ємів відповідних геометричних фігур.

Мета дослідження полягає в розробленні програмного забезпечення для побудови твірних поверхонь поперечного перерізу стовбурів деревини, іiі річних кілець, а також твірної поверхні колоди вздовж іiї осі, що дасть змогу підвищити точність та достовірність обліку деревини як промислової сировини в галузі деревообробки, а також уможливить дещо ефективніше її використання.

Для реалізації зазначеної мети потрібно виконати такі основні завдання:

1) розробити методику опису поперечних перерізів і твірних поверхонь стовбура деревини, яка б забезпечила визначення його розмірних характеристик і дала змогу врахувати форму колоди під час іiі обліку та визначення відповідних схем розкрою;

2) вибрати математичний апарат, розробити математичні моделі та алгоритми, що забезпечать адекватний опис форми поперечного перерізу стовбура деревини і його розмірні характеристики, а також дасть змогу здійснити індивідуальні заміри отриманої продукції після розкрою колод на пиломатеріали;
3) розробити програмне забезпечення, що реалізує побудову зазначених математичних моделей і алгоритмів на комп'ютері;

4) зробити відповідні висновки та надати рекомендації щодо використання розробленої методики складних геометричних поверхонь природного походження сплайн-функціями.

\section{1. Основні положення теорії сплайн-функцій}

Сплайн-функції - це математичний апарат наближення функцій, що інтенсивно розвивається та знаходить багато застосувань в різних прикладних задачах (Zavialov, Kvasov \& Miroshnichenko, 1980; Yakovlev, 1995). Поширення сплайн-функцій почалося в середині минулого століття при інтерполюванні складних кривих у прикладній геометрії. Класичним апаратом для розв'язання таких задач були інтерполяційні многочлени Лагранжа та Ньютона. Однак для великої кількості вузлів інтерполювання побудова таких многочленів $є$ складним завданням і при цьому зростають похибки інтерполювання (Makarov \& Khlobystov, 1993).

Апарат сплайн-наближення функцій дає змогу усунути недоліки многочленної інтерполяції. Основними перевагами такого апарату $є$ (Stechkin \& Subbotin, 1976):

- стійкість сплайнів відносно локальних збурень, тобто поведінка сплайна в околі точки не впливає на поведінку сплайна загалом, як, наприклад, це має місце при поліноміальній інтерполяції;

• добра збіжність сплайн-інтерполяції на відміну від многочленної;

- проста реалізація сплайн-функцій на комп'ютерах. Наприклад, побудова інтерполяційних сплайнів третього степеня зводиться до розв'язання систем лінійних алгебраїчних рівнянь 3 тридіагональною матрицею.

Простір сплайн-функцій. Нехай на проміжку $[a, b]$ задане розбиття $\Delta$ :

$$
a=x_{0}<x_{1}<\ldots<x_{n}=b .
$$

Для цілого $k \geq 0$ через $C^{k}=C^{k}[a, b]$ позначимо множину $k$ разів неперервно-диференційовних на проміжку $[a, b]$ функцій, а через $C^{-1}[a, b]-$ множину кусково-неперервних функцій з точками розриву першого роду.

Функція $S_{n, v}(x)$ називається сплайном $n$-го степеня дефекту $v(v-$ ціле число, $0 \leq v \leq n+1)$ з вузлами на сітці $\Delta$, якщо (Makarov \& Khlobystov, 1993; Stechkin \& Subbotin, 1976):

a) на кожному відрізку $\left[x_{i}, x_{i+1}\right]$ функція $S_{n, v}(x) \in$ многочленом $n$-го степеня;

б) $S_{n, v}(x) \in C^{n-v}[a, b]$.

Якщо $v=1$, то вважається, що $S_{n}(x)$ - сплайн $n$-го степеня (опускаючи слова "дефекту $1 ")$.

Отже, сплайн $S_{n, v}(x)$ має неперервні похідні до порядку $n-v$. Похідні сплайна вище $n-v$ порядку можуть мати розриви першого роду в точках $x_{i}, i=\overline{1, n-1}$. Для подальшої визначеності будемо вважати, що функція $S_{n, v}^{(r)}(x), r>n-v$, неперервна справа, тобто

$$
S_{n, v}^{(r)}\left(x_{i}\right)=S_{n, v}^{(r)}\left(x_{i}+0\right), r=\overline{n-v+1, n} ; i=\overline{0, n-1} .
$$

Множину сплайнів, що задовольняють умову (1), позначимо через $S_{n, v}^{(r)}(\Delta)$. Зрозуміло, що цій множині належать і сплайни степеня $n_{1}<n$ дефекту $v_{1}<v$, якщо $n_{1}-v_{1} \geq n-v$, в т.ч. многочлени степеня не вище $n$. Оскільки звичайні операції додавання елементів з $S_{n, v}(\Delta)$ i 
їх множення на дійсні числа не виходять за межі множини, то вона є лінійною множиною або лінійним простором (Makarov \& Khlobystov, 1993).

Згідно 3 даними, наведеними в роботі (Zavialov, Kvasov \& Miroshnichenko, 1980), простір сплайнів $S_{n, v}(\Delta) n$-го степеня дефекту $v$ на сітці $\Delta \epsilon$ скінченновимірним і його розмірність становить $n+1+v(n-1)$. Це о3начає, якщо кубічний сплайн дефекту 1 на сітці $\Delta$ має $n$ ну кількість вузлів, то розмірність цього простору становить $n+3$.

Аналітичне подання кубічного сплайна. Нехай на проміжку $[a, b]$ визначена деяка функція $f(x)$ і задана сітка $\Delta$. Кубічним інтерполяційним сплайном на сітці $\Delta$ для функції $f(x)$ називають функцію $S(x)$, що задовольняє такі умови (Makarov, \& Khlobystov, 1993):

$$
\left\{\begin{array}{l}
S(x) \in P_{3}(x), x \in\left[x_{j-1}, x_{j}\right], j=\overline{1, n} ; \\
S(x) \in C^{2}[a, b] ; \\
S\left(x_{j}\right)=f\left(x_{j}\right), j=\overline{0, n}
\end{array}\right.
$$

де $P_{3}(x)$ - множина многочленів 3-го степеня.

Використаємо такий підхід для опису алгоритму побудови інтерполяційних кубічних сплайнів. Насамперед введемо таке позначення

$$
S^{\prime \prime}\left(x_{j}\right)=M_{j}, j=\overline{0, n} .
$$

Зважаючи на те, що сплайн $S(x)$ на відрізку $\left[x_{j-1}, x_{j}\right]$ $\epsilon$ кубічним многочленом, то його друга похідна - лінійна функція такого вигляду:

$$
S^{\prime \prime}(x)=a x+b .
$$

Тоді, враховуючи позначення (4), маємо таку систему лінійних рівнянь

$$
\left\{\begin{array}{l}
a x_{j}+b=M_{j}, \\
a x_{j-1}+b=M_{j-1} .
\end{array}\right.
$$

Розв'язавши систему рівнянь (6), отримаємо такі їі корені

$$
a=\frac{M_{j}-M_{j-1}}{h_{j}}, \quad b=M_{j-1}-\frac{M_{j}-M_{j-1}}{h_{j}} x_{j-1},
$$

де $h_{j}, j=\overline{1, n}$ - відстань між вузлами інтерполяції.

Тоді друга похідна (5) матиме такий вигляд

$$
S^{\prime \prime}(x)=\frac{M_{j}}{h_{j}}\left(x-x_{j-1}\right)+\frac{M_{j-1}}{h_{j}}\left(x_{j}-x\right) .
$$

Проінтегрувавши рівність (8) двічі, отримаємо такий вигляд кубічного сплайна

$$
S(x)=\frac{M_{j}}{6 h_{j}}\left(x-x_{j-1}\right)^{3}+\frac{M_{j-1}}{6 h_{j}}\left(x_{j}-x\right)^{3}+C_{1} x+C_{2},
$$

де $C_{1}, C_{2} \in R-$ сталі інтегрування. Із умови інтерполяції знайдемо сталі $C_{1}, C_{2}$ :

$$
\begin{gathered}
C_{1}=\frac{y_{j}-y_{j-1}}{h_{j}}-\frac{h_{j}}{6}\left(M_{j}-M_{j-1}\right), \\
C_{2}=y_{j} \frac{x_{j}}{h_{j}}-M_{j-1} \frac{x_{j} h_{j}}{6}-y_{j} \frac{x_{j-1}}{h_{j}}+M_{j} \frac{h_{j} x_{j-1}}{6} .
\end{gathered}
$$

Підставивши $C_{1}$ і $C_{2}$ у рівність (9), отримаємо такий вигляд кубічного сплайна:

$$
\begin{gathered}
S(x)=\frac{M_{j}}{6 h_{j}}\left(x-x_{j-1}\right)^{3}+\frac{M_{j-1}}{6 h_{j}}\left(x_{j}-x\right)^{3}+\left(y_{j-1}-M_{j-1} \frac{h_{j}^{2}}{6}\right) \frac{x_{j}-x}{h_{j}}+ \\
+\left(y_{j}-M_{j} \frac{h_{j}^{2}}{6}\right) \frac{x-x_{j-1}}{h_{j}}, x \in\left[x_{j-1}, x_{j}\right], j=\overline{1, n} .
\end{gathered}
$$

Кубічний сплайн $S(x)$ на кожному відрізку $\left[x_{j-1}, x_{j}\right], j=\overline{1, n}$ визначається чотирма коефіцієнтами, тому для його побудови на проміжку $[a, b]$ потрібно $4 n$ коефіцієнтів. Умова (2) забезпечує неперервність кубічного сплайна і його похідних $S^{(r)}(x), r=\{0,1,2\}$, в усіх внутрішніх вузлах $x_{i}, i=\overline{1, n-1}$ сітки $\Delta$. Ця умова утворює 3(n-1) рівності для знаходження коефіцієнтів кубічного сплайна. Разом з рівностями (3) маємо 4n-2 співвідношень для побудови кубічного сплайна (10). Дві умови, що не вистачає, зручно задавати у вигляді обмежень (крайових умов) на значення кубічного сплайна та його похідних на кінцях проміжку $[a, b]$. Найбільш уживаними є такі типи крайових умов:

$$
\begin{aligned}
& S^{\prime}(y, a)=y^{\prime}(a), S^{\prime}(y, b)=y^{\prime}(b), \\
& S^{\prime \prime}(y, a)=y^{\prime \prime}(a), S^{\prime \prime}(y, b)=y^{\prime \prime}(b) .
\end{aligned}
$$

Із означення кубічного сплайна (1) маємо, що у внутрішніх вузлах сітки

$$
S^{\prime}\left(x_{j}+0\right)=S^{\prime}\left(x_{j}-0\right), j=\overline{1, n-1} .
$$

Обчисливши похідні кубічного сплайна відповідно до вигляду (10), матимемо

$$
\begin{gathered}
S^{\prime}\left(x_{j}+0\right)=\frac{y_{j+1}-y_{j}}{h_{j}}-\frac{h_{j}}{6}\left(2 M_{j}+M_{j+1}\right), \\
S^{\prime}\left(x_{j}-0\right)=\frac{y_{j+1}-y_{j}}{h_{j-1}}+\frac{h_{j-1}}{6}\left(M_{j-1}+2 M_{j}\right),
\end{gathered}
$$

звідки отримаємо набір рівнянь для обчислення величин $M_{j}$, а саме:

$$
\begin{gathered}
\mu_{j} M_{j-1}+2 M_{j}+\lambda_{j} M_{j+1}= \\
=\frac{6}{h_{j-1}+h_{j}}\left(\frac{y_{j+1}-y_{j}}{h_{j}}-\frac{y_{j}-y_{j-1}}{h_{j-1}}\right), j=\overline{1, n-1},
\end{gathered}
$$

де $\mu_{j}=\frac{h_{j-1}}{h_{j-1}+h_{j}}, \lambda_{j}=1-\mu_{j}$.

Цей набір рівнянь разом 3 крайовими умовами (11) або (12) утворюють систему рівнянь $n+1$ порядку відносно невідомих $M_{j}, j=\overline{0, n}$ такого вигляду:

$$
\left\{\begin{array}{l}
2 M_{0}+\lambda_{0}^{*} M_{1}=d_{0}^{*}, \\
\mu_{j} M_{j-1}+2 M_{j}+\lambda_{j} M_{j+1}=d_{j}, j=\overline{1, n-1}, \\
\mu_{n}^{*} M_{n-1}+2 M_{n}=d_{n}^{*},
\end{array}\right.
$$

де $d_{j}=\frac{6}{h_{j-1}+h_{j}}\left(\frac{y_{j+1}-y_{j}}{h_{j}}-\frac{y_{j}-y_{j-1}}{h_{j-1}}\right), j=\overline{1, n-1}$.

У випадку крайових умов типу (11) параметри системи рівнянь (15) є такими

$\lambda_{0}^{*}=\mu_{n}^{*}=1, \lambda_{0}^{*}=\frac{6}{h_{0}}\left(\frac{y_{1}-y_{0}}{h_{0}}-y_{0}^{\prime}\right), d_{n}^{*}=\frac{6}{h_{n-1}}\left(y_{n}^{\prime}-\frac{y_{n}-y_{n-1}}{h_{n-1}}\right)$,

а для крайових умов типу (12) матимемо

$$
\lambda_{0}^{*}=\mu_{n}^{*}=0, \lambda_{0}^{*}=2 y_{0}^{\prime \prime}, d_{n}^{*}=2 y_{n}^{\prime \prime}
$$

Матриця системи рівнянь (15) є тридіагональною (Stechkin \& Subbotin, 1976). Не складно побачити, що вона має переважаючу діагональ, а значить є невиродженою (Makarov \& Khlobystov, 1993). Це означає, що система рівнянь (15) має єдиний розв'язок.

Метод прогонки для побудови кубічних сплайнів. Для побудови кубічного інтерполяційного сплайна у вигляді (10) потрібно розв'язати систему рівнянь (15) 3 тридіагональною матрицею, що має діагональне переважання, яку можна записати у такому вигляді 


$$
\left\|\begin{array}{cccccc}
a_{1} & b_{1} & 0 & \cdots & 0 & 0 \\
c_{2} & a_{2} & b_{2} & \cdots & 0 & 0 \\
0 & c_{3} & a_{3} & \ddots & 0 & 0 \\
\cdots & \cdots & \cdots & \ddots & \cdots & \cdots \\
0 & 0 & 0 & \ddots & a_{n-1} & b_{n-1} \\
0 & 0 & 0 & \cdots & c_{n} & a_{n}
\end{array}\right\| \times\left|\begin{array}{c}
M_{1} \\
M_{2} \\
M_{3} \\
\cdots \\
M_{n-1} \\
M_{n}
\end{array}\right|=\left|\begin{array}{c}
d_{1} \\
d_{2} \\
d_{3} \\
\cdots \\
d_{n-1} \\
d_{n}
\end{array}\right| .
$$

Розв'язок системи рівнянь (18) шукатимемо у такому вигляді

$$
M_{i}=v_{i} M_{i+1}+u_{i}, i=\overline{1, n-1} .
$$

Використовуючи вираз для $M_{i-1} 3$ (19), вилучимо це невідоме $з$-го рівняння системи. Отримуємо вираз

$$
\left(a_{i}+c_{i} v_{i-1}\right) M_{i}+b_{i} M_{i+1}=d_{i}-c_{i} u_{i-1}, i=\overline{1, n-1} .
$$

Прирівнюючи це співвідношення до (19), отримуємо рекурентні формули для прогоночних коефіцієнтів $v_{i}, u_{i}$ (пряма прогонка):

$$
v_{0}=u_{0}=0, v_{i}=-\frac{b_{i}}{a_{i}+c_{i} v_{i-1}}, u_{i}=\frac{d_{i}-c_{i} u_{i-1}}{a_{i}+c_{i} v_{i-1}}, i=\overline{1, n} .
$$

Очевидно, що $M_{n}=u_{n}$. Всі інші невідомі знаходяться за формулами (20) (зворотна прогонка). Для реалізації алгоритму прогонки потрібно виконати $8 n$ арифметичних операцій: $3 n$ додавання, $3 n$ множення, $2 n$ ділення.

Алгоритм прогонки називається коректним, якщо всі дії, які необхідні для його реалізації, можна виконати. Дослідження коректності алгоритму прогонки зводиться до знаходження умов, при яких знаменники в формулах (20) не дорівнюють нулю.

Отже, наведено положення теорії сплайн-функцій, що обгрунтовують їх застосування для моделювання твірних поверхонь природного походження, які мають складну геометричну форму.

\section{2. Опис предметної області, постановка завдання дослідження}

Торці колод і схеми їх розкрою. Стовбур - це основна та найбільш цінна частина дерева (Hrytsiuk \& Koshyrets, 2014). 3 нього отримують від 60 до 90\% якісної та дорогої деревини. Місце розрізу стовбура перпендикулярно до його осі називається торием. На поперечному розрізі розрізняють серцевину, деревину, кору, камбій, річні шари, серцевинні промені (рис. 1).
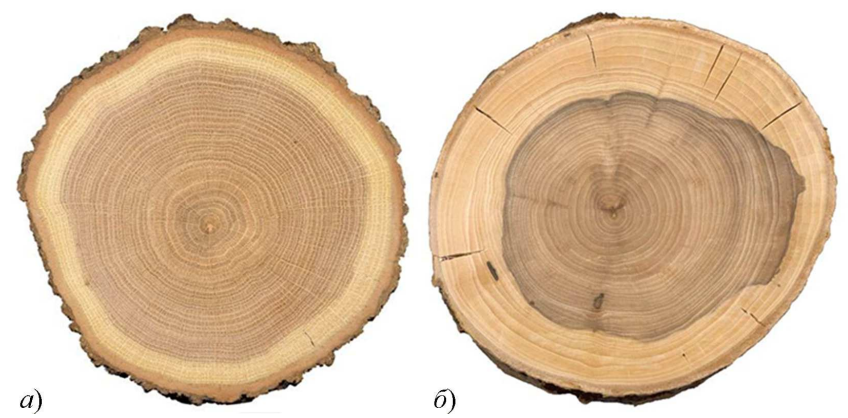

Рис. 1. Торці деревини складної геометричної форми

Серцевина складається 3 порівняно великих тонкостінних клітин, що утворилися в перші роки росту дерева (Gryciuk \& Yatsyshyn, 2007; Filiptcov, 2010). Діаметр серцевини у хвойних порід становить 2-3 мм, у листяних 3-5 мм. За період життя дерево щороку наростає в напрямку від серцевини до кори, відкладаючи при цьому концентричні кільця (шари) шириною від 3 до 8 мм залежно від породи дерева та природних умов його росту (Vovryn \& Hrytsiuk, 2018).
Зазвичай, стовбур деревини має довжину від 9 до 18 м, тому для подальшого оброблення його розпилюють на колоди довжиною від 3 до 6 м через 0,5 м. Отже, стовбур деревини певного діаметру і відповідної довжини називають колодою, придатною для розкрою на пиломатеріали певної товщини за відповідною схемою. Відомі різні схеми розкрою колод на пиломатеріали (Gryciuk \& Yatsyshyn, 2005a, 2005b).

При розкроюванні колоди за схемою "врозвал" (рис. 2) іiї пропускають через лісопильну раму один раз, розпилюючи на декілька необрізних дощок. За місцем розташування у колоді розрізняють серцевинну $\mathbf{1}$, центральні 2 та бокові 3 дошки, а також обапол 4.

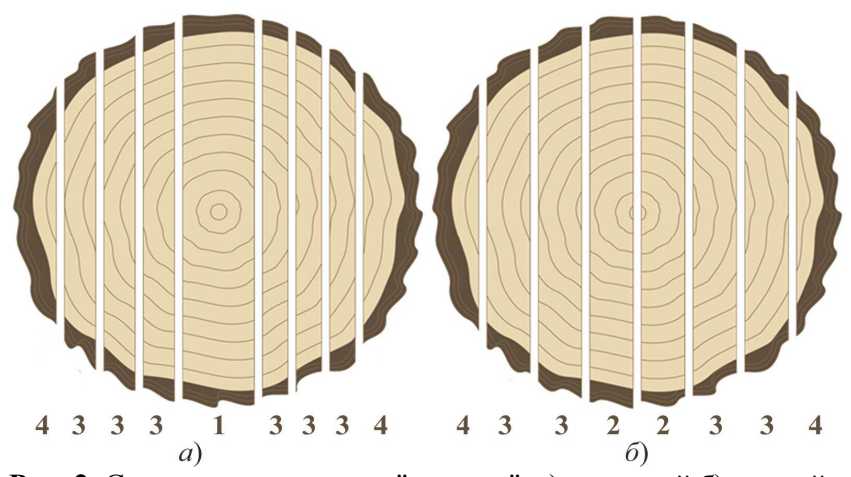

Рис. 2. Схема розкрою колод "врозвал": а) непарний б) парний постави: 1) серцевинна, 2) центральні та 3) бокові дошки, 4) обапол

При розкроюванні колод за схемою "з брусуванням" (рис. 3) колоду пропускають через лісопильну раму двічі. При першому проході через раму із середньої частини колоди випилюють двокантний брус 0, а $з$ бокових частин - необрізні дошки 3 і обаполи 4. При другому проході через раму пропускають двокантний брус $\mathbf{0}$, iз якого отримують у межах пропиляних пластей: б) чотирикантний брус 0' та обрізні дошки 3' і обаполи 4'; в) обрізні центральну $\mathbf{1}^{\prime}$ та бокові дошки $3^{\prime}$ і обаполи 4'.

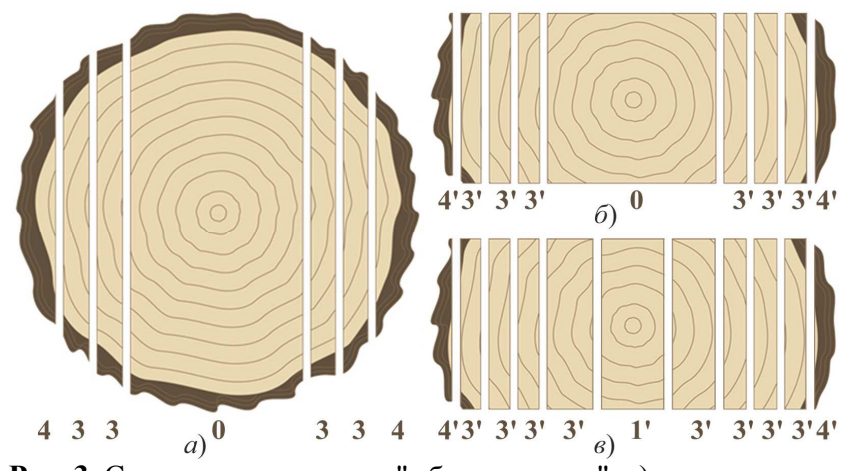

Рис. 3. Схема розкрою колод "з брусуванням": $a$ ) на двокантний брус та необрізні дошки; б) на чотирикантний брус та обрізні дошки; в) на обрізні дошки

Поставом називають групу пилок, що встановлені на певних відстанях між собою 3 метою одержання із колод дощок певних розмірів. У ширшому розумінні постав - це схема розкрою однорідних колод (певних діаметрів) на пиломатеріали певної товщини (Filiptcov, 2010). Постави, залежно від місця розташування відносно центра, можуть бути симетричними і несиметричними. Частіше при розкроюванні на лісопильних рамах застосовують симетричні постави. Несиметричні постави використовують тільки в особливих випадках, наприклад, при розкроюванні шпал та брусів. За кількістю дощок, що випилюють 3 колоди, постави бувають napними або непарними. 
Постав записують у вигляді цифрового ряду, що вказує на товщину дощок у міліметрах. Наприклад, для колоди діаметром 24 см, довжиною від 3 до 6 м можна скласти такий постав: $16-25-52-52-25-16$. Це постав на розкроювання колод за схемою "врозвал", парний та симетричний. В середині поставу знаходяться дві центральні дошки товщиною по 52 мм, потім дві бокові дошки по 25 мм, а також по краях дві бокові дошки товщиною по 16 мм. На основі цього поставу у вказаній послідовності встановлюють пилки 3 прокладками між ними.

При розкроюванні колод за схемою "з брусуванням" постав складають окремо на випилювання бруса, а потім для розкрою бруса за схемою "врозвал" на дошки відповідної ширини. Наприклад, діаметр колоди $24 \mathrm{~cm}$, довжина 6 м: 1-й прохід - 1 брус $\times 140$ мм, 4 дошки $\times$ 18 мм; 2-й прохід -5 дощок $\times 34$ мм, 4 дошки $\times 18$ мм. Скорочено це можна записати в такому вигляді:

$$
\frac{2}{18}-\frac{1}{140}-\frac{2}{18}, \frac{2}{18}-\frac{2}{34}-\frac{1}{34}-\frac{2}{34}-\frac{2}{18} \text {. }
$$

Це означає, що 3 колод діаметром 24 см при першому проході випилюють брус висотою (товщиною) 140 мм та по дві дошки товщиною 18 мм 3 кожного боку. При другому проході із середньої частини бруса випилюють п'ять дощок товщиною 34 мм та по дві дошки 3 кожного боку товщиною 18 мм.

Постави складають та розраховують наперед, тобто перед початком розкроювання колод на пиломатеріали. Від правильності складення та розрахунку поставів залежать продуктивність лісопильних рам та об'ємний вихід пиломатеріалів. Складанням та розрахунком поставів займається технолог лісопильного цеху.

Постановка завдання дослідження. На основі опису предметної області, можна сформулювати таку постановку завдання: розробити програмне забезпечення, за допомогою якого працівники лісопильних підприємств зможуть будувати точні геометричні моделі поверхні стовбура деревини та планувати раціональний розкрій колод на пиломатеріали.

Вхідними даними для майбутньої програми є положення теорії сплайн-функцій, теорії розкрою колод на пиломатеріали, методи і засоби відображення складних геометричних поверхонь, тестові набори зображень торців колод, отриманих з лазерної вимірювальної установки. Дані подано у вигляді списку координат $(x, y)$, отриманих по периметру торця колоди через кожні $10^{\circ}$.

Тестування розробленого програмного забезпечення та всі необхідні розрахунки проводились на схемі торця колоди, зображеної на рис. 4.
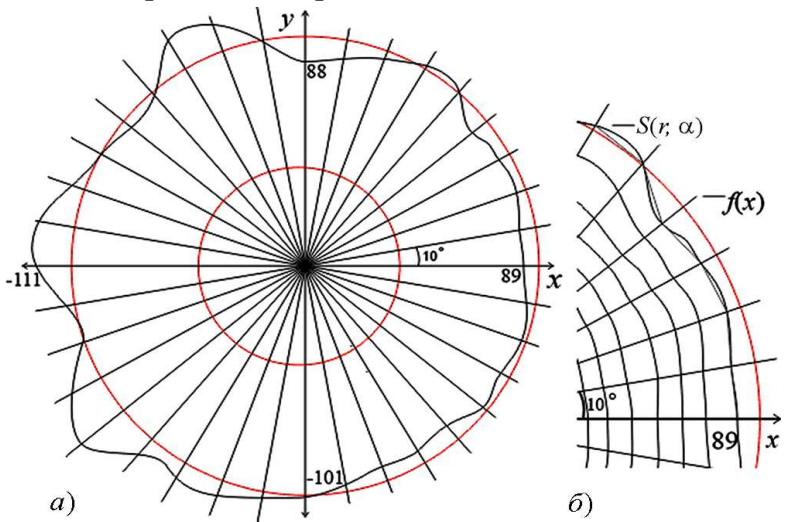

Рис. 4. Схема поперечного перерізу колоди $(a)$ і наближення твірної поверхні торця колоди кубічним сплайном (б)
Результатом дослідження має стати програмне забезпечення, готове до використання, основним функціоналом якого має бути побудова геометричних поверхонь торців колод сплайн-функціями, побудова різних схем розкрою колоди на пиломатеріали та їхній розрахунок, а також визначення виду випиляних пиломатеріалів - радіальних, тангентальних чи змішаних (Yatsyshyn \& Gryciuk, 2007). Програмний засіб має бути орієнтованим на користувачів, які є працівниками лісопильно-деревообробних підприємств. Його основною перевагою над наявними програмними продуктами має стати, насамперед, дружній інтерфейс користувача, на якому має відображатися увесь потрібний функціонал для досягнення необхідних результатів, а також відсутня прив'язка до конкретного оптико-вимірювального обладнання. Інтерфейс користувача має бути максимально простим і зрозумілим фахівцям деревообробних підприємств, що дасть змогу користувачу - технологу деревообробного цеху легко виконати потрібні дії та отримати бажані результати (Vovryn \& Hrytsiuk, 2018).

Отже, наведено загальну характеристику предметної області, що дало змогу обгрунтувати потребу підвищення точності та достовірності обліку стовбурів деревини в галузі деревообробки. Також наведено визначення основних термінів предметної області, що використовуються в галузі деревообробки, та схеми розкрою колод на пиломатеріали, що підтверджують доцільність використання сплайн-функцій для обліку колод та випиляних пиломатеріалів.

\section{3. Опис розроблених алгоритмів програмного за- безпечення}

Алгоритм масштабування річних кілець торця колоди. При виконанні цього дослідження важливою складовою побудови геометричної моделі торця колоди стала візуалізація річних кілець (Akho, Khopkroft, \& Ulman, 2000). Оскільки жодної інформації, окрім зовнішніх точок поверхні торця колоди, у нас немає, то на допомогу використаємо метод масштабування поверхні для побудови річних кілець (рис. 5,a).

Суть методу масштабування полягає в тому, що протягом року дерево наростає на товщину, яку можна обчислити за такою формулою

$$
R_{i-1}=R_{i}-\log _{a_{1-1}} R_{i} \cdot\left(1+\frac{R_{i}-R_{i}^{\min }}{a_{i-1} \cdot\left(R_{i}^{\max }-R_{i}^{\min }\right)}\right),
$$

де: $R_{i}, R_{i-1}-$ відповідно радіуси річного кільця попередній і наступний; $R_{i}^{\max }, R_{i}^{\min }-$ відповідно максимальне i мінімальне значення радіуса річного кільця; $a_{i-1}-$ основа натурального логарифма, можна визначити за такою емпыричною формулою

$$
a_{i-1}=-0,01 \cdot R_{i}^{\min }+2,7 .
$$

На рис. 5,б подано результати програмної реалізації побудови річних кілець торця колоди методом масштабування. 3 рисунка видно, що змодельовані цільця повністю відповідають річним кільцям реальної деревини.

Побудова схем розкрою колод на пиломатеріали. В роботі було розглянуто та використано такі основні схеми розкрою:

- розкрій колоди за схемою "врозвал" з не парним поставом (рис. 6,a);

- розкрій колоди за схемою "врозвал" з парним поставом (рис. 6,б);

- розкрій колоди за схемою "з брусуванням". 

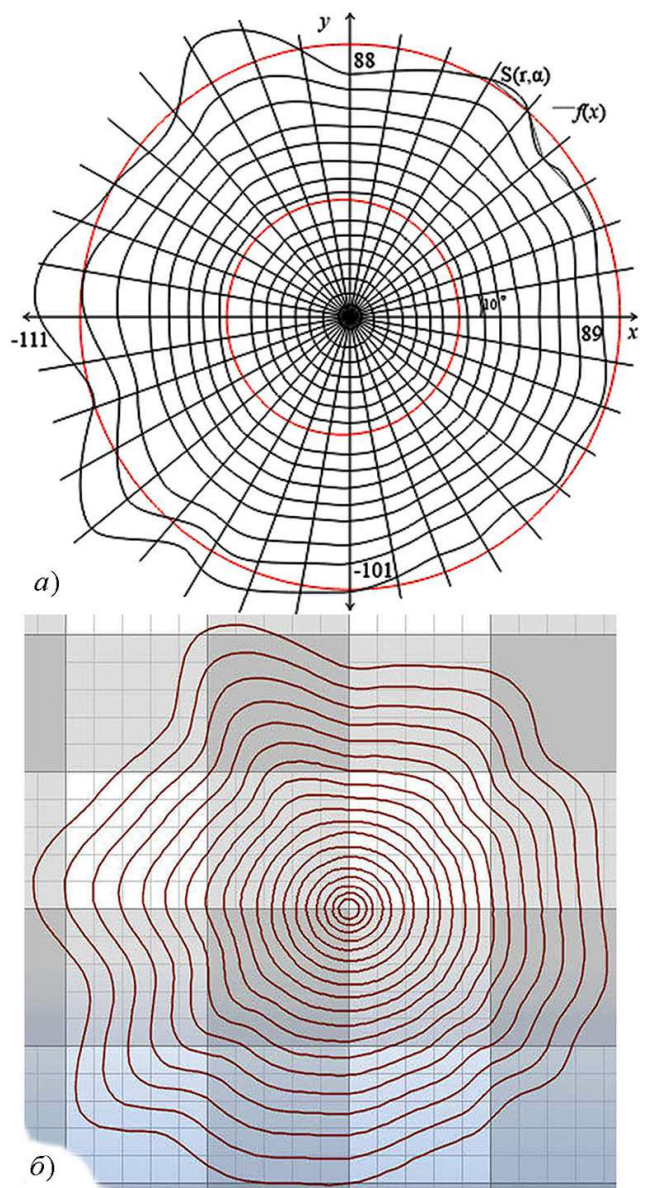

Рис. 5. Розрахункова схема побудови річних кілець торця колоди методом масштабування $(a)$ i його програмна реалізація (б)
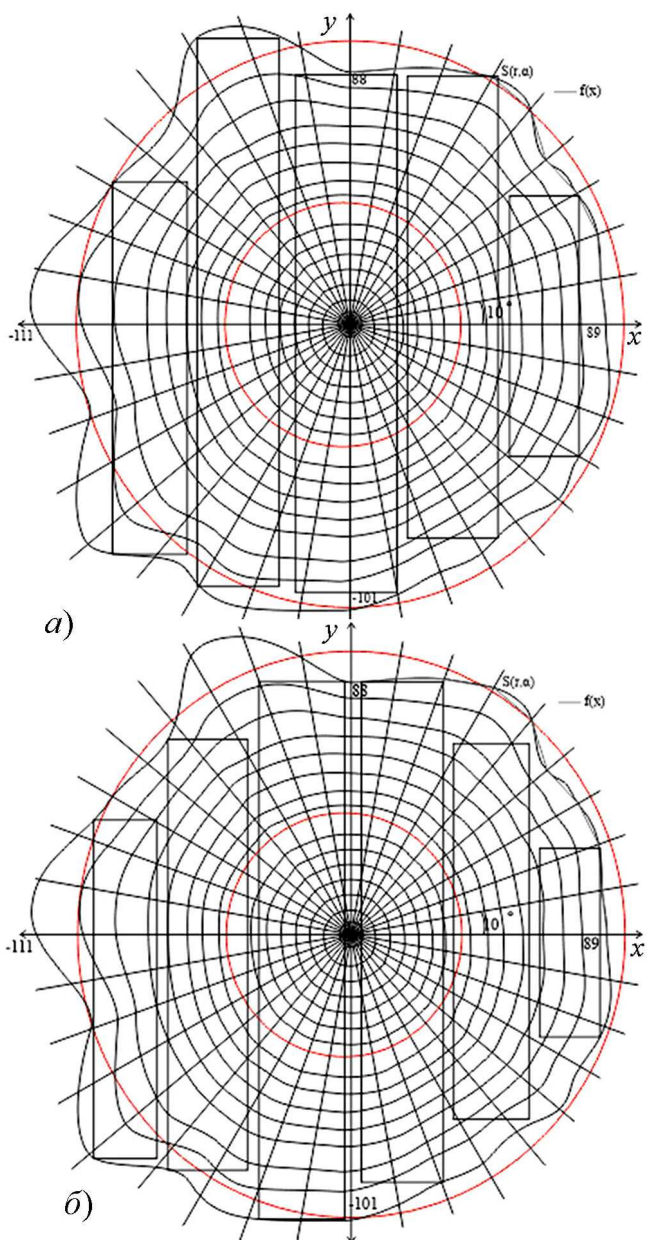

Рис. 6. Схеми розкрою колод на пиломатеріали: а) з серцевинною дошкою; б) з центральними дошками
Для всіх схем розкрою колод на пиломатеріали постав пил є змінним і залежить від введених даних (рис. 6). При розкроюванні колоди спочатку відбувається поділ її торця на сектори відносно схеми розкрою, а потім визначається їх допустима висота (ширина дощок) за мінімальною відстанню між його краями та відбувається так зване їх обрізання у відповідний стандартний розмір. При цьому спочатку визначають максимально можливу ширину дошки, яка можна помістити в межах твірної поверхні торця колоди, а потім здійснюється її приведення до стандартної чи заданої ширини у специфікації пиломатеріалів.

Обчислення площ складних геометричних поверхонь. Площу загального торця колоди обчислюють за формулою трикутників, де торець ділять точками отриманого сплайна на трикутні сектори 3 кутом, наприклад, в $1^{\circ}$ (рис. 7,a). Тоді площу торця колоди обчислюється за такою формулою:

$$
\left.S=\frac{\sin \alpha}{2} \sum_{i=1}^{360} a_{i-1} \cdot b_{i}=\frac{\sin \alpha}{2} \sum_{i=1}^{360} S(\alpha \cdot(i-1)) \cdot S(\alpha \cdot i)\right),
$$

де: $a_{\mathrm{i}-1}, b_{i}-$ довжини сторін $i$-го трикутника, які можна визначити через сплайн-функції $S(x)$; $\alpha$ - кут між ними, $\alpha=1^{\circ}$.

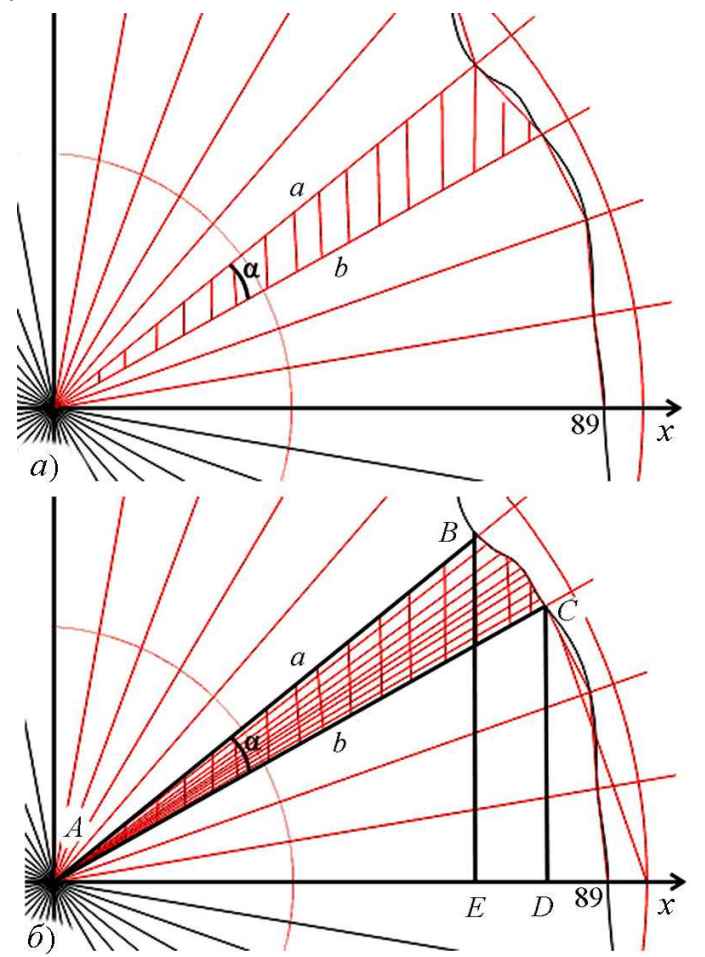

Рис. 7. Використання методу трикутників для обчислення площі торця колоди $(a)$ і частини необрізної дошки (б)

Для перевірки точності обчислення також площу торця колоди можна обчислити за формулою для визначення площі секторного багатокутника

$$
s_{1}=\frac{1}{2} \sum_{i=1}^{n+1}\left|y_{i} \cdot x_{i+1}-x_{i} \cdot y_{i+1}\right|,
$$

де $x_{i}$ та $y_{i}$ - координати вершин секторного багатокутника. Для обчислення площі необрізної дошки використовують обчислені площі фігури складної геометричної форми (рис. 7,б), частину якої можна описати кубічним сплайном на тій його поверхні, що входить в склад сектора $\mathrm{ABC}$, після чого потрібно додати площу трикутника під ним $(\triangle \mathrm{ACD})$ і відняти площу $\triangle \mathrm{ABE}$.

Обчислення виду випиляних пиломатеріалів. У собівартості пиломатеріалів понад 60\% припадає на си- 
ровину. Тому найважливішим показником ефективності виготовлених пиломатеріалів $\epsilon$ їх об'ємний вихід, зокрема - пиломатеріалів радіального і тангентального розкроювання. Об'ємний вихід пиломатеріалів, в основному, залежить від їх розмірів, точності опису форми колоди і визначення її об'єму та схеми розкрою.

В розробленому ПЗ реалізовані методи розкрою обрізних пиломатеріалів на пиломатеріали радіального i тангентального типів. Згідно 3 теоретичними даними, кут між дотичною до річних кілець та пластю пиломатеріалу відповідає за тип пиломатеріалу. При значенні кута до $30^{\circ}$ - пиломатеріал радіального типу, 30-60 радіально-тангентального, 60-90 - тангентального.

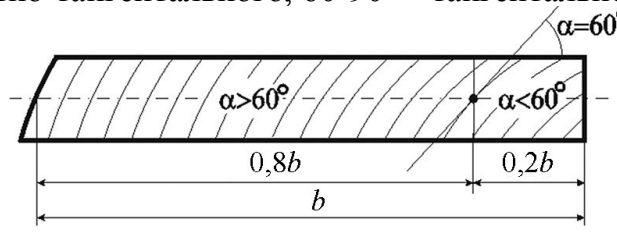

Рис. 8. Схема оцінювання радіальності на торці пиломатеріалу шириною $b, 3$ часткою радіальності $\rho=80 \%\left(\alpha=60^{\circ}\right)$

На основі результатів теоретичних досліджень встановлено, що кут між дотичною до річних кілець та пластю пиломатеріалу, змінюється по всій ширині пиломатеріалу (рис. 8). Розроблено математичні залежності для визначення кута між дотичною до річних кілець та пластю пиломатеріалу у будь-якій точці, ще до початку розкроювання й для визначення зон радіальності (тангентальності) на торці колоди:

$$
\begin{gathered}
\alpha=\operatorname{arctg}\left(S(x)^{\prime}\right)=\frac{a_{j}-y_{j}}{t}+ \\
+\frac{\left(b_{j}-2 a_{j}\right) \cdot\left(2 x-2 x_{j}\right)}{t^{2}}+\frac{\left(a_{j}-b_{j}\right)\left(3 x^{2}-6 x_{j} x+3 x_{j}^{2}\right)}{t^{3}},
\end{gathered}
$$

де $\alpha$ - кут між дотичною до річних кілець та пластю пиломатеріалу; $S(x)$ - сплайн-функція, що описує річне кільце, $t=x_{j+1}-x_{j}$.

Отже, наведено особливості проектування програмного забезпечення для побудови торця колоди складної геометричної форми, описано проектні рішення стосовно предметної області, що дає змогу розробити, а також визначити основні дії для досягнення поставленої мети. Також наведено опис вибраних алгоритмів розв'язання поставлених задач, які базуються на теорії інтерполяції кубічними сплайнами, що дало змогу адекватно побудувати твірні поверхні колод різної геометричної форми.

\section{4. Реалізація програмного забезпечення}

Програмне забезпечення (ПЗ) для побудови складних геометричних поверхонь природного походження сплайн-функціями було розроблено згідно з вимогами до виконання роботи. Воно розроблено у вигляді виконуваного файлу, що не потребує жодних додатково встановлених програм чи файлів для успішного виконання всіх поставлені завдань дослідження.

Головна сторінка запуску ПЗ має вигляд, як показано на рис. 9. 3 лівого боку екрану розташоване меню додатку, що розгортається та містить кнопки переходу на основні сторінки: побудова геометричної поверхні торця колоди, побудова об'ємної моделі, детальна інформація про схеми розкрою та настанови користувача. Також головне меню ПЗ містить сторінки для роботи 3 усіма сутностями системи. Користувач має доступ до таких функцій: "Побудова твірної поверхні", "Побудова об'ємної моделі", "Схеми розкрою" та "Настанова користувача" (Vovryn \& Hrytsiuk, 2018).

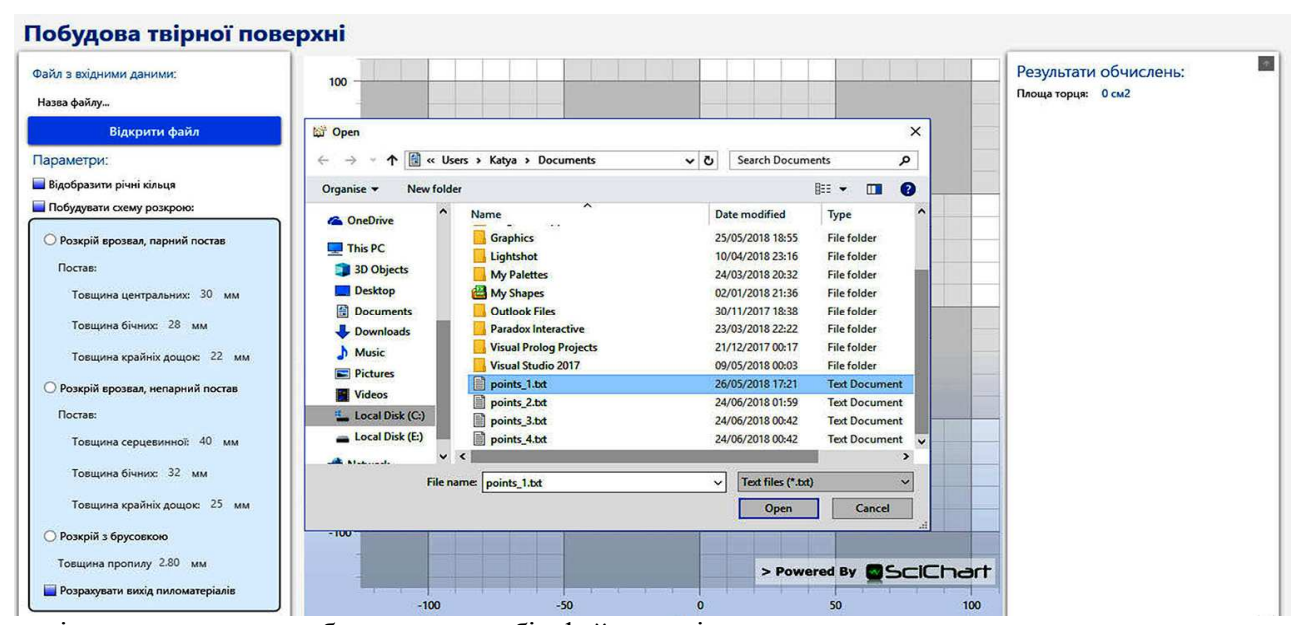

Рис. 9. Головна сторінка програмного забезпечення, вибір файлу з вхідними даними

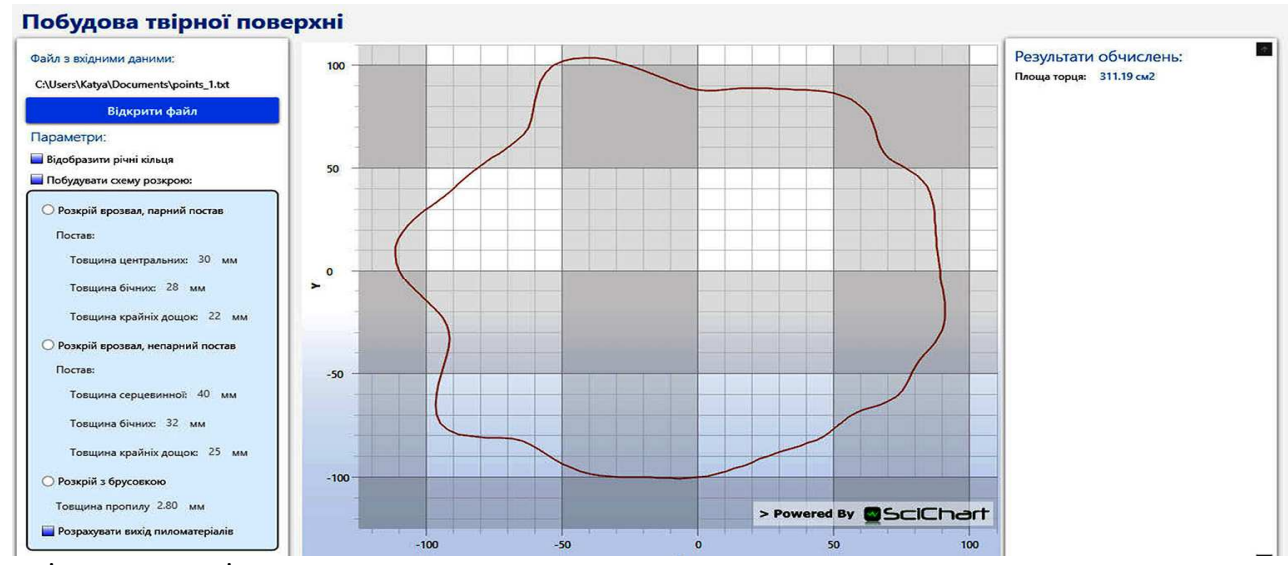

Рис. 9. Побудова твірної поверхні торця колоди 

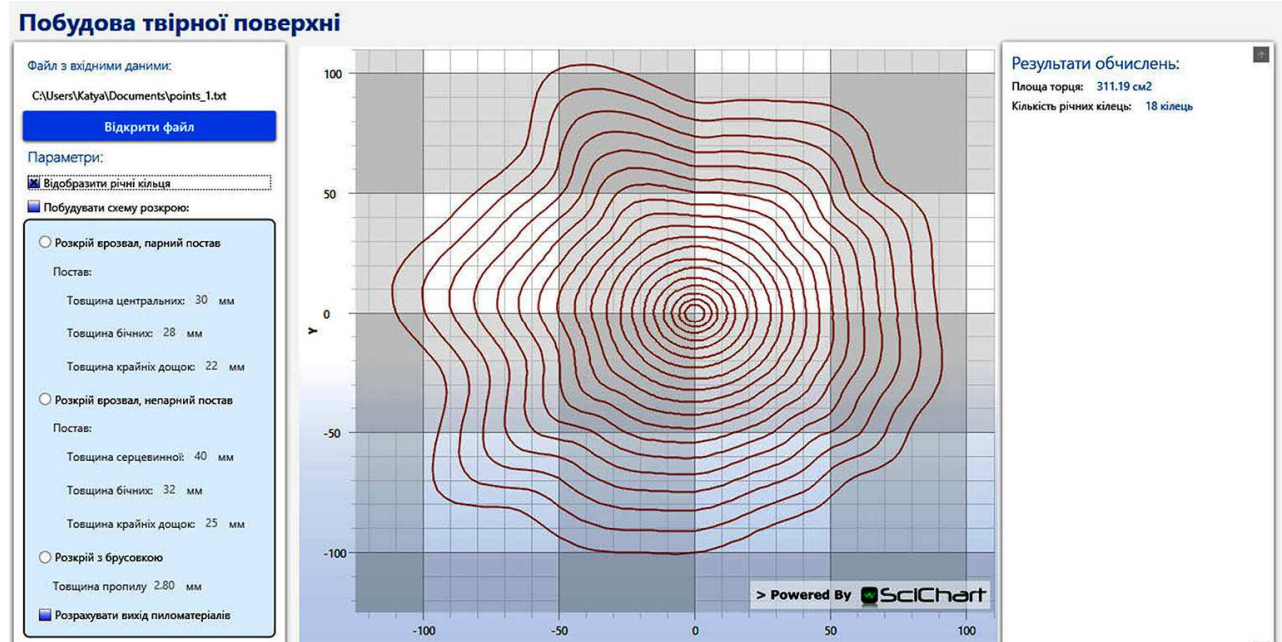

Рис. 10. Побудова річних кілець торця колоди за його твірною поверхнею Побудова твірної поверхні
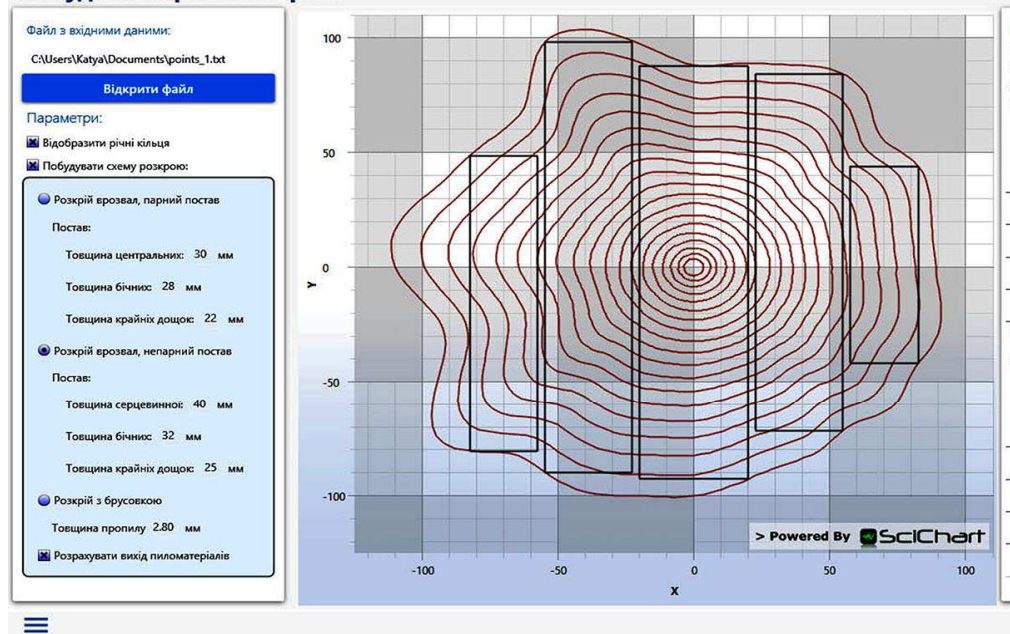

Побудова твірної поверхні
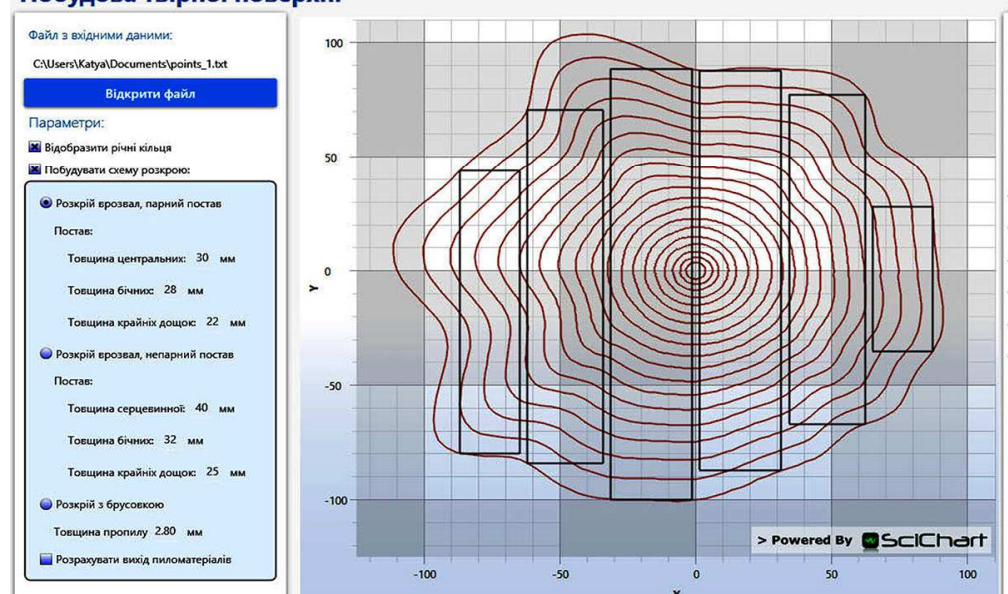

Рис. 11. Побудова схеми розкрою з серцевинною (а) і центральними дошками (б)

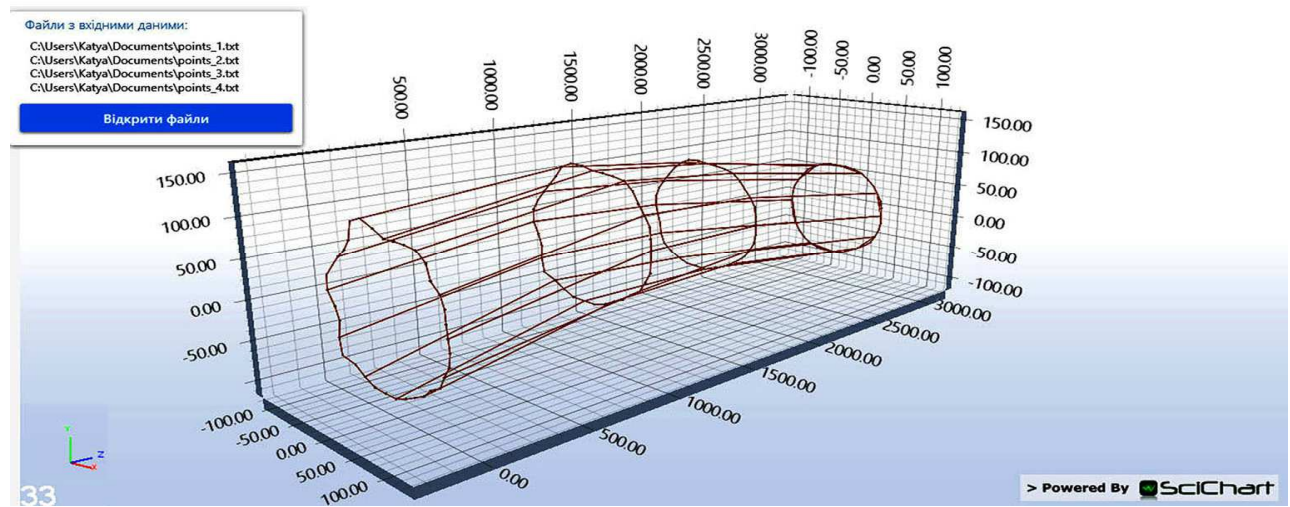

Рис. 12. Побудова об'ємної моделі твірної поверхні колоди 
Отже, описано програмну реалізацію проектного рішення, що здійснює побудову моделей твірних поверхонь колоди сплайн-функціями, алгоритми обліку стовбура деревини і окремі алгоритми побудови схем розкрою у вигляді програмних засобів для ПК відповідно до поставлених вимог. Наведено приклади роботи розробленого програмного забезпечення з описом його основних характеристик, яке дає змогу зчитати вхідні дані, здійснювати побудову зображення твірної поверхні торця колоди, здійснювати побудову річних кілець за його твірною поверхнею та змоделювати схему розкрою колоди на пиломатеріали 3 обчисленням їх об'ємного виходу та виду випиляних пиломатеріалів.

\section{Висновки}

Розроблено програмне забезпечення для побудови складних геометричних поверхонь природного походження, а саме - стовбура деревини за допомогою сплайн-функцій, що дає змогу підвищити точність та достовірність ії обліку (колод різних розмірних характеристик), а також випиляних пиломатеріалів у галузі деревообробки. На підставі виконаної роботи можна зробити такі основні висновки:

1. Проведено аналіз предметної області моделювання твірних поверхонь стовбура деревини кубічними сплайнами, що дало змогу визначити підходи до розроблення програмного забезпечення, яке підвищить точність та достовірність обліку колод як промислової сировини в галузі деревообробки. 3'ясовано, що метод побудови математичних моделей твірних поверхонь поперечного перерізу колод і їх поверхонь вздовж осі дає змогу на основі єдиного теоретичного підходу описати їх розміри та форму осей і зовнішніх поверхонь. Він заснований на вимірюванні координат певної кількості точок поперечного перерізу стовбура деревини уздовж iї довжини і подальшої інтерполяції точкового базису. Встановлено, що математичний апарат - інтерполяційні кубічні сплайни, побудовані на невеликій кількості точок поверхні, дають змогу з достатньою точністю визначити розмірні показники і врахувати особливості форми стовбурів деревини (кривизну, збіжність, овальність), а також є адекватними індивідуальними моделями для обліку колод як деревини, так і випиляних 3 них пиломатеріалів.

2. Зроблено постановку задачі моделювання складних геометричних поверхонь природного походження кубічними сплайнами, що дало змогу конкретизувати основні цілі та вимоги до програмного забезпечення, яке потрібно розробити. Визначено, що основними завданнями при розробленні програмного забезпечення $\epsilon$ побудова твірних поверхонь поперечного перерізу колод кубічними сплайн-функціями, масштабування твірної торця колоди для побудови річних кілець та обчислення як його площі, так і виходу випиляних пиломатеріалів за різними схемами розкрою.

3. Наведено всі основні технічні особливості проектування програмного забезпечення для побудови твірних поверхонь торця колоди складної геометричної форми, спроектовано відповідний інтерфейс користувача для зручності роботи технолога цеху з програмним забезпеченням, описано вибрані алгоритми розв'язання поставлених задач. Виявлено, що базування алгоритмів на теорії інтерполяції кубічними сплайнами дає змогу адекватно побудувати твірні поверхні як торців колод різної геометричної форми, так і її твірних зовнішньої поверхні вздовж осі з врахуванням іiї кривизни.

4. Реалізовано програмне забезпечення для побудови твірних поверхонь стовбурів деревини складної геометричної форми, яке дає змогу здійснити побудову моделей поверхонь колод сплайн-функціями. Наведено алгоритми обліку стовбура деревини і окремі алгоритми схем розкрою колод на пиломатеріали. Досліджено, що вихід пиломатеріалів після здійсненого математичного моделювання значно збільшується порівняно 3 іншими способами моделювання поверхонь колод.

5. Встановлено, що метод індивідуальних моделей стовбурів деревини, їх математична, програмна й апаратна підтримка у вигляді математичних моделей, алгоритми реалізації та програмне забезпечення, результати i висновки поданих досліджень можуть бути використані при проектуванні лісопильних виробничо-технологічних систем, створення ресурсоощадних технологічних процесів деревооброблення на основі сучасного технологічного та вимірювального обладнання й методів інформаційних і комп'ютерних технологій.

6. Зроблено відповідні висновки та надано рекомендації щодо використання розробленої методики побудови складних геометричних поверхонь природного походження сплайн-функціями.

\section{Перелік використаних джерел}

Akho, A. V., Khopkroft, D., \& Ulman, D. D. (2000). Struktury dannykh $i$ algoritmy. Moscow: Izd. dom "Viliams". 384 p. [In Russian].

Filiptcov, M. V. (2010). Razrabotka matematicheskogo obespecheniia, algoritmov i kompleksa tekhnicheskikh sredstv sistem avtomatizirovannogo ucheta lesomaterialov. Abstract of Doctoral Dissertation for Technical Sciences (05.13.06 - Automation and management of technological processes and industries (by industry)). Voronezh. 18 p. [In Russian].

Gryciuk, Yu. I., \& Koshyrets, S. I. (2009). Kompleksne vykorystannia derevyny kolod khvoinykh porid u protsesi vyhotovlennia pylomaterialiv. Proceedings of the Forestry Academy of Sciences of Ukraine, 7, 139-146.

Hrytsiuk, Yu. I., \& Koshyrets, S. I. (2014). Modeli ta metody rozkroiu kolod na radialni pylomaterialy: monohrafiia. Lviv: Vyd-vo LDU BZhD. 216 p. [In Ukrainian].

Gryciuk, Yu. I., \& Yatsyshyn, S. I. (2005). Vyznachennia optymalnykh skhem rozkroiu kolod na radialni pylomaterialy. Scientific Bulletin of UNFU, 15(3), 115-124.

Gryciuk, Yu. I., \& Yatsyshyn, S. I. (2005a). Problema identyfikatsii poverkhon kolod, vypylianykh zi stovburiv derev khvoinykh porid. Proceedings of the Forestry Academy of Sciences of Ukraine, 4, 132-138.

Gryciuk, Yu. I., \& Yatsyshyn, S. I. (2007b). Rozrakhunok obiemnoho vykhodu pyloproduktsii ta vidpovidnykh vidkhodiv metodamy chyslovoho intehruvannia. Bulletin of the National University "Lviv Polytechnic". Series: Computer Science and Information Technology, 598, 61-69.

Makarov, V. L., \& Khlobystov, V. V. (1993). Splain-approksimatciia funktcii: ucheb. posob. dlia stud. VUZov. Moscow: Izd-vo "Vysshaia shk.". 80 p. [In Russian].

Stechkin, S. B., \& Subbotin, Iu. N. (1976). Splainy v vychislitelnoi matematike. Moscow: Glavn. red. fiz.-mat. lit-ry izd-va "Nauka". 248 p. [In Russian].

Vovryn, K. Ya., \& Hrytsiuk, Yu. I. (2018). Prohramne zabezpechennia dlia pobudovy skladnykh heometrychnykh poverkhon za dopomohoiu splain-funktsii. Tsyvilizatsiia. Prohres. Novi vymiry: zb. materialiv mizhdystsyplin. nauk.-prakt. konf., (p. 41-46), 15 chervnia 2018 r., m. Kyiv, Ukraina. Kyiv: Yudina L. I. 118 p. Retrieved from: http://futurolog.com.ua/publish/10/ Zbirnyk.pdf\#page $=41$. [In Ukrainian]. 
Yakovlev, M. K. (1995). Sovershenstvovanie ucheta i raskroia kruglykh lesomaterialov na osnove metoda individualnykh modelei. Abstract of Doctoral Dissertation for Technical Sciences (05.21.05 - Wood Science, Technology and Equipment for Woodworking). Minsk. 18 p. [In Russian].
Yatsyshyn, S. I., \& Gryciuk, Yu. I. (2007). Metodyka vyznachennia ta analiz optymalnykh skhem rozkroiu kolod na radialni pylomaterialy. Scientific Bulletin of UNFU, 17(1), 136-146.

Zavialov, Iu. S., Kvasov, B. I., \& Miroshnichenko, V. L. (1980). Metody splain-funktcii. Moscow: Izd-vo "Nauka". 352 p. [In Russian].

Начиональный университет "Львовская поли. Грыцюк, К. Я. Воврин

ПРОГРАММНОЕ ОБЕСПЕЧЕНИЕ ДЛЯ ПОСТРОЕНИЯ СЛОЖНЫХ ГЕОМЕТРИЧЕСКИХ ПОВЕРХНОСТЕЙ С ПОМОЩЬЮ СПЛАЙН-ФУНКЦИЙ

Разработано программное обеспечение для построения сложных геометрических поверхностей природного происхождения - ствола дерева с помощью сплайн-функций, что позволяет повысить точность и достоверность его учета по различным размерным характеристикам, а также выпиленных из него пиломатериалов в области деревообработки. Установлено, что метод построения математических моделей образующих поверхностей поперечного сечения бревен и их поверхностей вдоль оси позволяет на основе единого теоретического подхода описать их размеры и форму осей, а также наружных поверхностей. Он основан на измерении координат определенного количества точек поперечного сечения ствола дерева вдоль ее длины и последующей интерполяции точечного базиса. Установлено, что математический аппарат - интерполяционные кубические сплайны, построенные на небольшом количестве точек поверхности, позволяют с достаточной точностью определить размерные показатели бревен и учесть особенности формы ствола древесины (кривизну, сходимость, овальность), а также являются адекватными индивидуальными моделями для учета бревен как промышленного сырья, так и выпиленных из них пиломатериалов. Определено, что основными задачами при разработке программного обеспечения является построение образующих поверхностей поперечного сечения бревен кубическими сплайнами, масштабирование образующей торца бревна для построения годовых колец и вычисления как его площади, так и выхода выпиленных пиломатериалов по разным схемам раскроя. Реализовано программное обеспечение для построения образующих поверхностей стволов древесины сложной формы, которое позволяет осуществить построение моделей поверхностей бревен сплайн-функциями. Приведены алгоритмы учета ствола древесины и отдельные алгоритмы схем раскроя бревен на пиломатериалы. Доказано, что выход пиломатериалов после реализации математического моделирования значительно увеличивается по сравнению с традиционными методами моделирования поверхностей бревен. Установлено, что метод индивидуальных моделей стволов древесины, их математическая, программная и аппаратная поддержка в виде математических моделей, алгоритмы реализации и программное обеспечение, результаты и выводы представленных исследований могут быть использованы при проектировании производственно-технологических систем деревообработки, создания соответствующих ресурсосберегающих технологических процессов на основе современного технологического и измерительного оборудования, методов и моделей информационных технологий.

Ключевые слова: информационные технологии; программный проект; ствол дерева; поперечное сечение бревна; образующая поверхность; годовые кольца; схема раскроя; пиломатериалы; технологическое оборудование; ресурсосберегающий технологический процесс.

Yu. I. Hrytsiuk, K. Ya. Vovryn

Lviv Polytechnic National University, Lviv, Ukraine

\section{THE SOFTWARE FOR CONSTRUCTION COMPLEX GEOMETRIC SURFACES BY MEANS OF SPLINE FUNCTIONS}

It was developed the software for the construction of complex geometric surfaces of natural origin - a tree trunk using spline functions. It allows you to increase the accuracy and reliability of accounting of wood in different dimensional characteristics, as well as sawn timber in the field of woodworking. It was found that the method of constructing mathematical models of forming the crosssectional surface of logs and their surfaces along the axis allows based on a single theoretical approach to describe the dimensions and shape of the axes, as well as external surfaces. It is based on the measurement of coordinates certain amount of the cross-section of a tree trunk points along its length and the subsequent interpolation point basis. It was found that the mathematical implementation - interpolating cubic splines, constructed on a small number of surface points, allow to determine with sufficient accuracy, the dimensional indices logs and incorporate features of the form of timber barrel (curvature, convergence, ovality). The cubic splines are also the adequate individual models to account for the logs as an industrial raw material and timber sawn from them. It was determined that the main objectives of software development is the construction of the cross-sectional surfaces forming logs cubic splines, scale forming butt logs for the construction of the annual rings and calculating his area and the output of sawed sawn timber for different cutting patterns. The software for constructing forming surfaces of complex shape of trunks of wood, which makes it possible to build models of surfaces logs by spline functions was implemented. The algorithms accounting for wood barrel and some algorithms schemes cutting logs for timbers are given. It is proved that the output of sawn timber after the implementation of mathematical modelling is significantly increased in comparison with the traditional methods of modelling the surfaces of logs. It was found that the method of individual models of trunks of wood, their mathematical, software and hardware support in the form of mathematical models, algorithms, implementation and software, the results and conclusions of the presented research can be used in the design of production and processing of wood systems, the establishment of appropriate resource-saving technological processes on the basis of modern technology and measuring equipment, methods and information technology models.

Keywords: information technology; software design; tree trunk; cross-section of the log; forming surface; annual rings; cutting scheme; timber; technological equipment; resource-saving process. 